\title{
Sundarbans mangrove deltaic system - An overview of its biodiversity with special reference to fish diversity
}

\author{
Suvra Roy*, Vikash Kumar, R.K. Manna and V.R. Suresh \\ ICAR- Central Inland Fisheries Research Institute (CIFRI), (Barrackpore-700120), INDIA \\ *Corresponding author. E-mail: suvrar6@gmail.com
}

Received: May 16, 2015; Revised received: March 5, 2016; Accepted: April 15, 2016

\begin{abstract}
World heritage site-Sundarbans were declared as the world's $560^{\text {th }}$ Ramsar Wetlands site in 1992. Sundarbans ecosystem supports rich fisheries diversity and also natural biodiversity hot spot, because it is natural habitat of many endangered species. The Sundarbans is a home to a variety of faunal species, the total of 1586 species has been recorded which includes 481 Vertebrate species (30\%), 1104 Invertebrate species (70\%). Mangroves are the nursery and breeding grounds for several commercially important species of aquatic fauna like fish, shrimps and prawns etc. Mangrove ecosystems are of great ecological significance in the tropical and sub-tropical coast. Sundarbans mangrove provides a variety of ecosystem services. However, the Sundarban mangrove forest is the most threatened habitats in the world, increased population with few alternative livelihood opportunities poses a serious threat as it is the main cause of mangrove destruction. The total value of Sundarbans is not recognized and therefore often neglected in development planning. As a result Sundarbans conservation issue is getting less importance at the national level. The study reveals that major ecosystem services of Sundarbans are timber, fuel wood, fish, ecotourism, cyclone and storm protection, biodiversity, and habitat for flora and fauna. Timber, fuel wood and fish are more economical provisioning services in Sundarbans. It is noticed that there is decreasing tendency of overall revenue collection from the mangrove over the period of 2001-02 to 2009-10. The attention from national and international communities is needed for sustainable management and conservation of the Sundarbans. The study suggests that further research on total economic value of Sundarbans is needed for providing comprehensive scientific information for policy as well as for decision makers.
\end{abstract}

Keywords: Biodiversity, Fish diversity, Mangrove, Sundarbans, World heritage site

The Sundarban forest is the largest estuarine mangrove forest in the world located in 24 Paraganas district of West Bengal (India) and Bangladesh (Pasha and Siddiqui, 2003; Das et al., 2012). It lies on the GangesBrahmaputra Delta at the point, where it merges with the Bay of Bengal. The forest consists of about 200 islands, separated by about 400 interconnected tidal rivers, creeks and canals (Banglapedia, 2010; Das et al., 2012). It covers an area of about 1 million ha, of which $60 \%$ is located in Bangladesh and the remaining is western portion, comprising $40 \%$ lies in India. In India, it covers an area of $9630 \mathrm{~km}^{2}$ out of which $4266 \mathrm{~km}^{2}$ is Mangrove forest (Naskar, 2000). Sundarbans region includes $4263 \mathrm{~km}^{2}$ of Reserve Forest (inclusive of $1678 \mathrm{~km}^{2}$ of South 24 Parganas Reserve Forest \& $2585 \mathrm{~km}^{2}$ of Sunderban Tiger Reserve. The Sundarbans was originally measured (about 200 years ago) to be of about $16,700 \mathrm{~km}^{2}$. Now it has dwindled to about $1 / 3$ of the original size (Rahman and Asaduzzaman, 2010).

Geographical location: The forest lies a little south to the Tropic of Cancer between the latitudes $21^{\circ} 30^{\prime} \mathrm{N}$ and $22^{\circ} 30^{\prime} \mathrm{N}$, and longitudes $89^{\circ} 00^{\prime} \mathrm{E}$ and $89^{\circ} 55^{\prime} \mathrm{E}$. The Sundarbans Reserved Forest (SRF) is situated in the extreme south-west corner of Bangladesh between the river Baleswar and Harinbhanga adjoining to the Bay of Bengal and it covers $6017 \mathrm{~km}^{2}$ out of which $4,143 \mathrm{~km}^{2}$ is land area and $1,874 \mathrm{~km}^{2}$ is water area comprising rivers and tidal waterways (Fig. 1) (Alongi, 2009). The forest is bounded in the north by the private settlement, in the south by the Bay of Bengal, in the east by the Baleshwar River and in the west by the Harinbhanga, Raimongal and Kalindi River which is also the international boundary with India and to the north (Information Sheet on Ramsar Wetlands, 2001).

Sundarban National Park: The Sundarban National Park is a National Park, Tiger Reserve and a Biosphere Reserve in West Bengal, India. It is part of the Sundarbans on the Ganges Delta, and adjacent to the Sundarban Reserve forest in Bangladesh. The delta is densely covered by mangrove forests, and is one of the largest reserves for the Bengal tiger also home to a variety of bird, reptile and invertebrate species, including the salt-water crocodile. The present Sundarban National Park was declared as the core area of Sundarban Tiger Reserve in 1973 and a wildlife sanctuary in 1977 (Khan, 2011). The Directorate of forest is responsible for the 
administration and management of Sundarbans. The endangered species that lives within the Sundarbans are Royal Bengal Tiger, Saltwater Crocodile, River Terrapin, and Olive Ridley Turtle, Gangetic dolphin, Ground Turtle, Hawks Bill Turtle and Mangrove horseshoe crab (Junk et al., 2006).

Unique recognition of Sundarban: The Govt. of India declared the Sundarbans region including the protected area of Sundarban Tiger Reserve as Biosphere Reserve in 1989. It received the recognition of UNESCO, under its Man \& Biosphere (MAB) Programme, in Nov. 2001. Sundarban Tiger Reserve was constituted by Govt. of India under "Project Tiger" scheme, in 1973. It is covering an area of $2585 \mathrm{~km}^{2}$, out of which $1330 \mathrm{~km}^{2}$ is the core zone and $1255 \mathrm{~km}^{2}$ is the buffer zone. Considering the importance of Sundarban's Bio-geographic Region, the national park area of the Sundarban tiger reserve has been included in the list of world natural heritage sites in 1985. Sundarban national park, forming the core area of Sundarban tiger reserve, received recognition as world heritage site by UNESCO in 1987. Sundarban has been nominated by Govt. of India (GOI) for recognition as Ramsar Site (a wetland of international importance). In 1992, the Sundarban were declared a Ramsar site wetland, enlarging its area from 596,000 to 601,700 hectares of forest reserve, part of its area was allocated to wildlife sanctuaries (Fig. 2).

The Sundarbans were declared as the world's $560^{\text {th }}$ Ramsar Wetlands site and includes the following wetland types: F (Estuarine waters), G (Intertidal mud, sand, or salt flats), I (Intertidal forested wetlands), and M (Permanent rivers/ streams/-creeks) (Fig. 3). The international importance and inclusion of the Sundarbans as a Ramsar wetlands site was based on Ramsar wetlands selection criteria $1 \mathrm{c}, 2 \mathrm{a}, 2 \mathrm{~b}, 2 \mathrm{c}, 3 \mathrm{~b}$, and $4 \mathrm{~b}$ (Islam and Gnauck, 2009). Based on the policies of Ramsar Convention 1971, some specific steps of management and conservation are taken by the Govern-

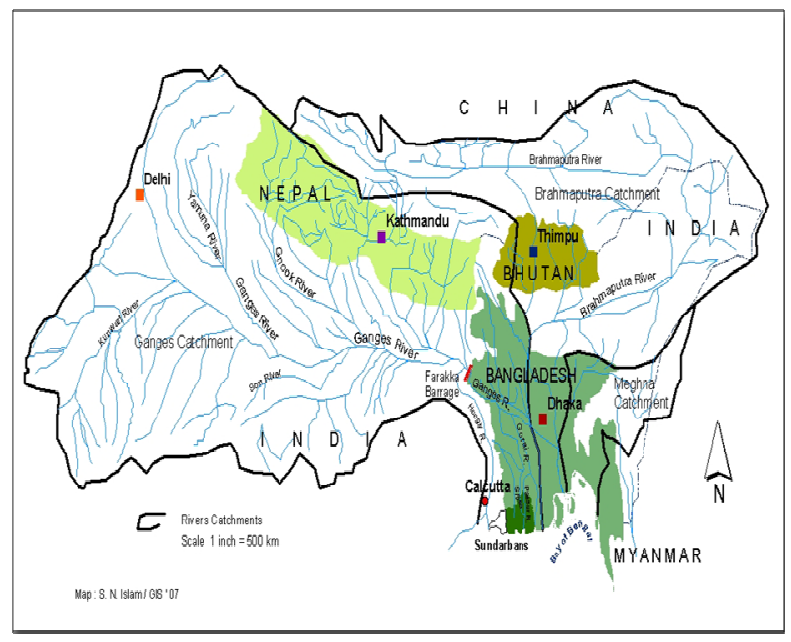

Fig. 1. Map Geographical location of the Sundarbans in the Ganges catchment (Islam and Gnauck, 2009). ment of Bangladesh and India which is now at the implementation stage. In 1997, the Indian portion of the Sundarbans was identified as a UNESCO Man and Biosphere (MAB) reserve area. The Bangladesh portion is under consideration as an MAB reserve (Islam and Gnauck, 2009). The only mangrove forest on the planet Earth sustaining the population of the Royal Bengal tiger (Panthera tigris tigris). Sundarban tiger reserve has the highest tiger population in the world. The deltaic lobe has contrasting salinity profile. The western sector is hyposaline, whereas the central sector is hypersaline (Zaman et al., 2013).

Biodiversity of Sundarbans: The ecology and the biodiversity of the Sundarban has been extensively studied (Prain 1903; Champion 1936; Mukherjee 1975; Jain and Sastry 1983; Sanyal 1983; Naskar and Mandal 1999; Sen and Naskar 2003, Naskar and Guha Bakshi 1987) the mangrove ecosystem with reference to human habitation, settlement, development of agricultural fields and brackish water fisheries. The large spatial and temporal variability in hydrological regimes (both freshwater inflows and the tides), topography, texture of the substratum, the salinity, and their interactions, result in very high habitat heterogeneity in the mangrove ecosystems, and thereby ensure an equally diverse biodiversity. Overall, there are relatively small differences between the species composition of the India and Bangladesh parts. Sundarban has extremely rich diversity of aquatic and terrestrial flora and fauna (Table 1).

Mangroves are associated with flowering plants, palms, ferns, bryophytes, fungi, algae, lichens and bacteria. Fauna have been poorly studied in comparison to flora Macintosh and Ashton (2002), but according to FAO estimates, Sundarban mangrove forest is home to about 840 species of wild animals, including 419 Royal Bengal tigers (MoEF, 2004). The Sundarban Mangrove Forests has been home for a wide biodiversity. Sundarbans is a natural biodiversity hot spot, be-

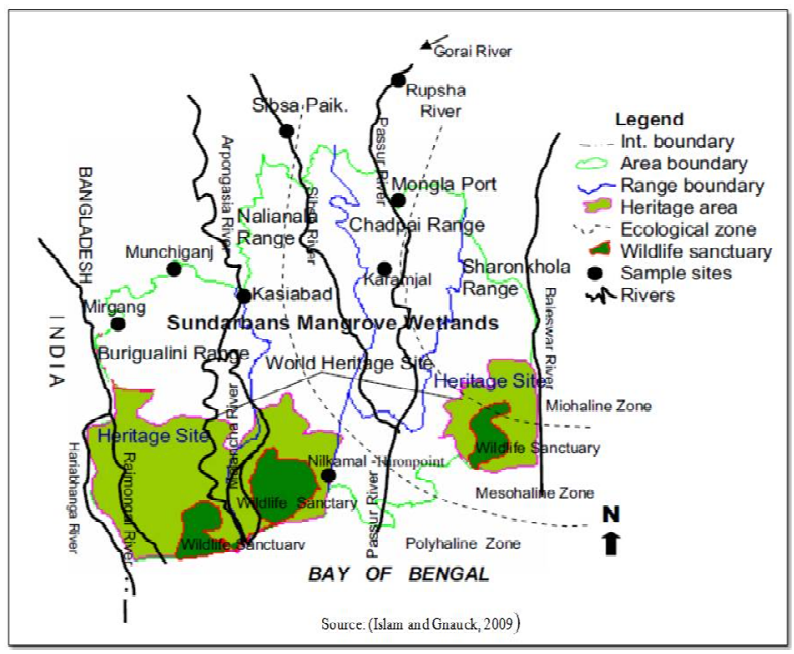

Fig. 2. Sundarbans mangrove wetland ecosystem (Islam and Gnauck, 2009). 

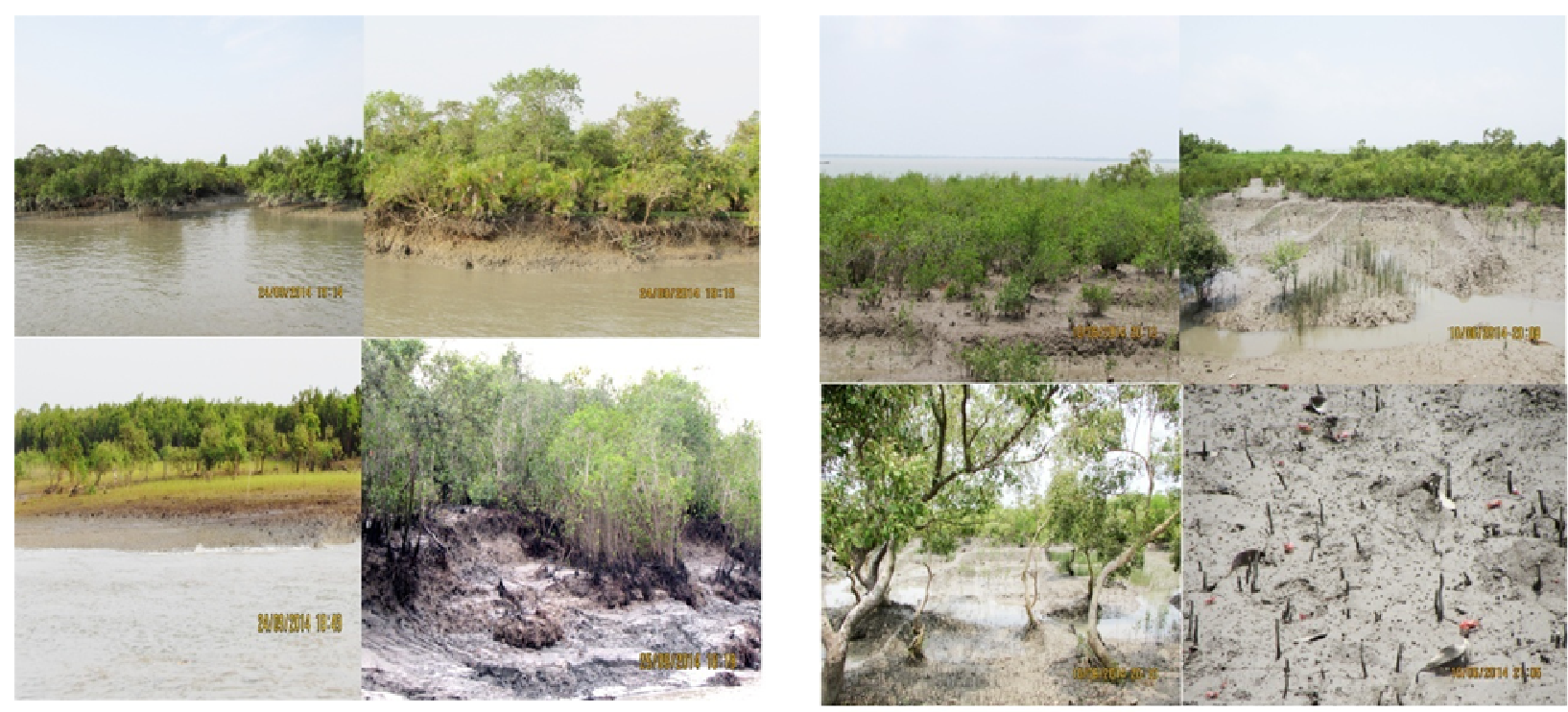

Fig. 3. An overview of Sundarbans mangrove .

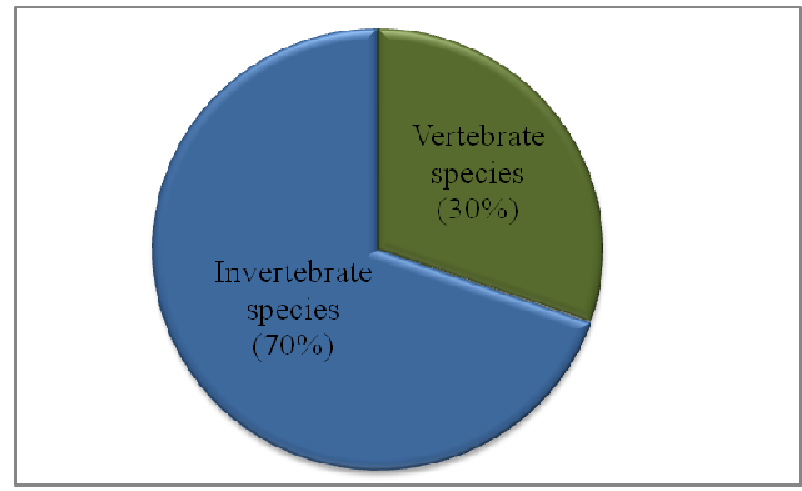

Fig. 4. Vertebrate and invertebrate species of Sundarbans mangrove.

cause it is natural habitat of many endangered species (Table 2).

Floral diversity: The Sundarbans mangrove has the highest number of mangrove and swamp flora (Naskar and Guha-Bakshi 1987; Gopal and Chauhan, 2006). The floristic composition of Sundarbans was first described with 334 species and 245 genera in 75 families of plants including small to large trees, shrubs, climbers, grasses and herbs (Prain, 1903; Uddin, 2011). So far, no similar study and detailed inventory have been made on the vegetation, although Overseas Development Administration (ODA) (1985) has listed 130 species of commonly found higher plants and (Islam 1976) has reported 165 species of algal flora around the mangrove ecosystem. However, among various types of plants some are endemic to the Sundarbans, e.g. sundari (Heritiera fomes), gewa (Excoecaria agallocha), goran (Ceriops decandra) and keora (Sonneratia apetala). The Sundri is the unique species of the Sundarban Ramsar Site. The forest is rich in epiphytic ferns, parasitic plants and orchids; among the 66 species of orchids found in the forest about 13 are epiphytic (Table 3).

The Sundarbans flora is characterised by the abundance of sundari (Heritiera fomes), gewa (Excoecaria agallocha), goran (Ceriops decandra) and keora (Sonneratia apetala) all of which occur prominently throughout the area. The principal tree species is Sundari (Heritiera fomes) which covers about $73 \%$ to total landmass and the second species is Gewa (Excoecaria agallocha) which covers about $16 \%$ of total forest area (Rahman and Asaduzzaman, 2013). New forest accretions are often conspicuously dominated by keora (Sonneratia apetala) and tidal forests . There is abundance of dhundul or passur (Xylocarpus granatum) and kankra (Bruguiera gymnorrhiza) though distribution is discontinuous. Among palms, Poresia coaractata, Myriostachya wightiana and golpata (Nypa fruticans), and among grasses spear grass (Imperata cylindrica) and khagra (Phragmites karka) are well distributed. The varieties of the forests that exist in Sunderbans include mangrove scrub, littoral forest, saltwater mixed forest, brackish water mixed forest and swamp forest (Rahman and Asaduzzaman, 2013).

Besides the forest, there are extensive areas of brackishwater and freshwater marshes, intertidal mu dflats, sandflats, sanddunes with typical dune vegetation, open grassland on sandy soils and raised areas supporting a variety of terrestrial shrubs and trees (Gopal and Chauhan, 2006). Since Prain's report there have been considerable changes in the status of various mangrove species and taxonomic revision of the man-grove flora (Khatun and Hafiz, 1987). However, very little exploration of the botanical nature of the Sundarbans has been made to keep up with these changes. Differences in vegetation have been explained in terms of freshwater and low salinity influences in the Northeast and variations in drainage and siltation. The Sundarbans has been classified as a moist tropical forest demonstrating a whole mosaic of seres, comprising primary colonisation on new accretions to more mature beach forests. Historically vegetation types have been recognised in broad correlation with varying degrees of water salinity, 
freshwater flushing and physiography (Khatun and Hafiz, 1987). The vegetation of Sundarbans is unique in many respects such as floristic diversity, composition, association and abundance. It is also interesting to note that tree height is relatively shorter in SouthWestern parts and longer in North-Eastern parts of the forest. It acts as a natural safeguard to protect the entire coastal region at the north of Sundarbans from cyclones and tidal bores. The environmental importance of the forest as green shelterbelt can be assumed from the devastation and death toll caused by such catastrophic events in the coastal areas where there is no mangrove forest like Sundarbans (Amin, 2002).

Faunal diversity: The fauna of the Sunderban has attracted much attention because of the huge economic importance of many species. The Sundarbans is the only remaining habitat in the lower Bengal Basin for a variety of faunal species. With regard to wildlife, the Sundarbans possesses a rich faunal diversity even after disappearance of a good number of interesting species (Table 4). The Sundarbans is a home to a variety of faunal species. The total of 1586 species has been recorded which includes 481 Vertebrate species (30\%), 1104 Invertebrate species (70\%) and Hemi-Chordate 1 species (Fig. 4).

The Sundarbans mangrove forest is a unique habitat of euryhaline / brackish water algae, shell-fish and fin-fish species, prawns, crustaceans, estuarine crabs, ghost shrimps, mollusks, nematodes, annelids, animals like various types such as jungle cat, the deer, rhesus monkey, wild pig, otter, water monitor, various snakes, including python, estuarine crocodiles, sharks, dolphins, large variety of local birds and migratory pelicans (Banerjee 1998; Bose 2002). The biodiversity is, however, under threat owing to man - mangrove conflict and the increasing salinity Sen and Naskar (2003). Also, the Sunderban is the only mangrove forest with a species of the tiger the Royal Bengal Tiger (Panthera tigris tigris), according to the 2011 tiger census, about 270 Bengal tigers left over in this forest (www.bforest.gov.bd/highlights.php). With regard to mammals, birds, reptiles and the amphibians, the Sundarbans shares $45,42,46$ and $36 \%$ respectively with the rest to the country (Zöckler et al., 2005).

Crustaceans account for the largest proportion of animal biomass e.g. fiddler crabs, mud crabs besides a considerable harvest of shrimps, prawns and lobsters. The Sunderban supports very rich estuarine and coastal marine fisheries. Among the diversity of insects, honeybees hold an important position for the production of large quantities of honey and beeswax. Estuarine crocodile Crocodylus porosus still survives but its numbers have been greatly depleted through hunting and trapping for skins. Besides, 10 species of mammals, 11 species of birds, 16 species of reptiles and one species of amphibian is endangered (Siddiqi 2001).

Fisheries diversity: The Sundarban ecosystem supports rich fisheries diversity (Table 5). Considerable research work by Hamilton and Buchanan 1822; Kemp 1917; Annandale 1922; Hora 1933; Pantulu 1966; Shetty et al. 1961 and Talwar and Joglekar 1970 has been undertaken and contributed in many aspects of fish biology in the Sundarbans. Gopalkrishnan (1971); Sen (1975); Naskar and Guha Bakshi (1987); Mandal and Nandi (1989); Chaudhuri and Choudhury (1994); Bose et al. (1999); Sanyal (1999); Debnath (2001); Khan (2003) and Naskar (2004) have reported the fish and fishery resources of the Sundarban mangrove based estuary.

Mangroves are also the nursery and breeding grounds for several commercially important species of aquatic fauna, e.g. shrimps Penaeus monodon, mud crab Scylla serrata, Hilsa Tenualosa ilisha, Pomadasys hasta, Polynemus sp. and Coilia sp. etc. (Saenger 2002). Although many shrimps and crabs are reported from Sundarbans, among them shrimps Penaeus monodon (Fabricius, 1798) and Metapenaeus monoceros (Fabricius, 1798) and the mud crab Scylla serrata (Forsskal, 1775) are commercially important. Over 120 species of fish are said to be commonly caught by commercial fishermen Seidensticker and Hai (1983). The shallow swamps around the mangroves sustain an ideal breeding and nurshing ground for fishes, juvenile shrimps and endangered species such as olive ridley turtle, gangetic dolphin (Platanista gangetica) (Roxburgh, 1801), hawks bill turtle (Eretmochelys imbricate) and King Crab (Carcinoscorpius rotundicauda). The fish diversity is directly related to the salinity gradients in different parts (i.e. interior mudflats, middle stretches and transition zones or ecotones between riverine and marine habitats) of the Sunderban. Fishes such as Harpodon nehereus, Trichiurus savala, Setipinna sp., Pampus $s p$., Sardinella sp. and Salar sp. occur in areas with salinity, whereas Pangasius pangasius and Lates calcarifer occur in freshwater areas or those with very low salinity. The dominant fishes in brackish waterzones (moderate salinity) are Hilsa (Tenualosa) ilisha, Pomadasyshasta, Polynemus sp. and Coilia sp. Several marine fishes also often occur within the mangroves. The fisheries of Sundarbans are very important for local economy and livelihoods of thousands of poor people living around and outside the landscape area. It produces $2-5 \%$ of the total capture fisheries (Rabbani and Sarker 1997; Rahman et al., 2013). Many species of palaemonid shrimps are also associated with mangroves, including the commercially important giant freshwater shrimp, Macrobrachium rosenbergii (Macnae 1974; Matthes and Kapetsky 1988; Singh et al., 1994). Mangroves also support vast numbers of small shrimp of which Acetes spp. (Sergestidae) are the most important to fisheries (Macnae 1974; Macintosh 1982). The mangrove crab fauna is of major ecological and economic importance (Macnae 1974; Macintosh 1982; Matthes and Kapetsky 1988), including the high-priced mangrove mud crab, Scylla serrata. A total of 67 species of finfish were identified of which the representatives from the order Perciformes are dominant (Mandal et al., 2012). Mangrove plants association is one of the great sources of pigmentation for the estuarine fishes. The estuarine fin fishes also collect their body pigments from many other food sources like algae, crustaceans and molluscs.

Importance of Sundarbans mangrove forest ecosystem: Mangrove ecosystems are of great ecological significance in the tropical and sub-tropical coast. They protect our coast from heavy wind, tidal waves, coastal 
erosion and sea water intrusion, generate substantial quantities of fishery resources and provide many useful forestry products. The ecosystem forms an ideal ecological asset because the production of leaf litter and detrital matter from mangrove plants full fill the nutritional requirements of prawn juveniles, adult shrimps, mollusks, and fishes of high economic value. That is why mangrove ecosystem is recognized as the world's most potential nursery (Zaman et al. 2013). The highly specialized mangrove ecosystem also acts as the protector of the coastal landmass from storm surges, tropical cyclones, high winds, tidal bores, seawater seepage, and intrusion. Bioaccumulation of heavy metals by certain mangrove species (e.g. the grey mangrove Avicennia marina has a relatively higher tolerance, Aegiceras corniculatum, Rhizophora stylosa, Hibiscus tiliaceus, Excoecaria agallocha, Bruguiera gymnorhiza and Ceriops tagal (Anouti 2014; Saenger and McConchie, 2004) reveals a most surprising feature about these plants as they can act as bio -purifier or bio-filter. Certain mangrove species are highly efficient in detecting or assessing the change of ambient environment. The concentration of heavy metal pollutants in different parts of mangrove plants may act as a pathfinder for water quality monitoring program (Mitra et al., 2004). Eturbinata have shown strong in vivo activity against a variety of cancer cells. Phenols and flavonoids in mangrove leaves serve as UV screening coumpounds. Hence, mangrove leaves can tolerate solar UV radiation and create a UV free, under canopy environment (Moorthy, 1995). Mangroves and mangrove habitats contribute significantly to the global carbon cycle. Twilley, Chen, and Hargis (1992) estimated the total global mangrove biomass to be approximately 8.70 gigatons dry weight (which is equivalent to 4.00 gigatons of carbon). Accurate biomass estimation, however, needs the measurement of the volumes of individual trees. This property of mangrove vegetation has immense significance in reducing carbon dioxide concentrations in the atmosphere and subsequent rise in temperature. Mangroves constitute an important ecosystem because of their global extent and high productivity. The survival and growth of mangroves are regulated by salinity. Zaman et al. (2013) reported that considerable salinity difference has occurred between the western and central Indian Sundarbans over a period of more than two decades. Such variation has affected the growth pattern of sensitive mangrove species in the Indian Sundarbans region. The above-ground biomass (AGB) of Heritiera fomes has increased consistently in the western Indian Sundarbans, whereas in the central Indian Sundarbans the change in AGB is almost uniform. The primary reason for such variation in salinity is the siltation in the Bidyadhari channel since the late $15^{\text {th }}$ century that has cut off the supply of freshwater in the central Indian Sundarbans. The Sundarbans region has a warm humid climate. It receives rainfall during the southwest monsoon season, which starts in June and continues until October, with occasional rainfall throughout the year. In the Sundarbans, during the monsoon rains, the estuarine regime is influenced by the interaction of the headwater discharge and the tides, which together influence the seaward drift of the sediment. During reduced inflow of freshwater, strong tidal currents govern the estuary and influence the upstream sediment movement (Rahmanand and Asaduzzaman 2010). The forest land is highly influenced by tidal interactions because of the presence of these water bodies. The forest receives freshwater and sediment from a number of distributaries of the Ganges. Each one of the following elements of the ecosystem namely climate, salinity, siltation, erosion, substrate and nutrients have first order reaction on flora and fauna.

Threats to Sundarbans biodiversity: Sundarban mangrove forest is the most threatened habitats in the world (Rahman 2009). The increased population with few alternative livelihood opportunities (e.g., crop farming, livestock) poses a serious threat to the Sundarban as it is the main cause of mangrove destruction (Ong 1995; FAO 2003; Ali et al., 2006). Excessive exploitation and negligence of restocking are the main cause of overall depletion of growing stocks of Sundarban forest (Ali et al., 2006).

The growing stock of the Sunderban forest has depleted from 20.3 million $\mathrm{m}^{3}$ in 1959 to 10.9 million $\mathrm{m}^{3}$ in 1996 (FAO 2000). The sundarbans mangrove ecosystems are delicate, dynamic and complex and their principal parameters are the environment, the flora, the fauna and human interference (Choudhury, 1984). The threats to the Sundarban mangrove eco-system are arising partly due to biotic pressure from the surrounding environment and, partly due to human induced or natural changes in the upper catchments. Different anthopogenic activity like reclamation, human encroachment and influence, geomorphic stress caused by the neo-tectonic tilting of the Bengal basin, etc. causes recurrent coastal flooding due to climate change (global warming), changes in sea level (raise in sea level), huge silt deposition, biodiversity loss and regeneration problems of obligate mangrove plants, high salinity, low water table and acidity problem, loss of soil fertility, coastal erosion, steep fall in fishery resources, reduction in the periodicity and quantity of freshwater reaching the mangrove environment due to diversion of freshwater in the upstream areas (especially due Farakka Barrage constructed by India) and change in course of main rivers, conversion of mangrove tracts for aquaculture and agriculture, uncontrolled collection of prawn seedlings and fishing in the water of reserve forests, pollution from both the landward and seaward sides through marine paints \& hydrocarbons , usage of excessive pesticides \& chemicals for agricultures \& industries, exploitation of mineral gas and oil and Lack of public awareness etc (Rahman, 2009). Over-exploitation of forests to meet the growing requirement of the people is one of the main problems facing the Sundarbans. Encroachment, 
Table 1. IUCN Red list species in Sundarban.

\begin{tabular}{|c|c|c|c|}
\hline Mugger crocodile & Crocodylus palustris & Extinct & $\begin{array}{l}\text { As a result of past over- } \\
\text { exploitation }\end{array}$ \\
\hline Olive ridley & Lepidochelys olivacea & Endangered & $\begin{array}{l}\text { Among marine turtles most } \\
\text { abundant }\end{array}$ \\
\hline Royal Bengal Tiger & Panthera tigers & Endangered & \\
\hline Jungle Cat & Felis chaus & Endangered & \\
\hline Irrawaddy/dolphin & Orcaella brevirostris & Endangered & \\
\hline Blyth's Kingfisher & Alcedo hercules & Endangered & \\
\hline Estuarine Crocodile & Crocodilus porosus & Endangered & \\
\hline Yellows Monitor & Varanus flavescens & Endangered & Present \\
\hline Rock python & Python molurus & Endangered & \\
\hline Green Frog & Euphlyctis hexadactylus & Endangered & \\
\hline Green sea turtle & Chelonia mydas & Endangered & Rare due to excessive fishing \\
\hline Hawksbill turtle & Eretmochelys imbricata & Critically Endangered & Not common although there \\
\hline Loggerhead & Caretta caretta & Endangered & have been some Reported \\
\hline River terrapin & Batagur baska & Endangered & Present \\
\hline Gangetic dolphin & Platanista gangetica & & \\
\hline King Crab & Carcinoscorpius rotundicauda & & \\
\hline Javan rhinoceros & Rhinoceros sondaicus & Extinct & \\
\hline Indian python & Python molurus & Not Threatened & \\
\hline
\end{tabular}

(Source: Siddiqi 2001; Rahman and Asaduzzaman 2010)

Table 2. Local Species of Sundarbans.

\begin{tabular}{|c|c|c|}
\hline \multicolumn{2}{|l|}{ Local/common name } & Scientific name \\
\hline \multicolumn{2}{|l|}{ Roya Bengal Tiger } & Panthera tigris tigris \\
\hline \multicolumn{2}{|l|}{ Saltwater crocodile } & Crocodylus porosus \\
\hline \multicolumn{2}{|l|}{ Water monitors } & Varanus salvator \\
\hline \multicolumn{2}{|l|}{ Rhesus monkey } & Macaca mulatta \\
\hline \multirow[t]{4}{*}{ Jackal } & & Canis aureus \\
\hline & Little Cormorant & Phalacrocorax niger \\
\hline & Open-bill stork & Anastomus oscitans \\
\hline & Common pochard & Aythya farina \\
\hline \multirow[t]{2}{*}{ Bird species } & White stork & Ciconia ciconia \\
\hline & Common redshank & Tringa tetanus \\
\hline Giant honeybee & & Apis dorsata \\
\hline Javan rhinoceros (extirpated) & & Rhinoceros sondaicus \\
\hline Wild buffalo (extirpated) & & Bubalus bubalis \\
\hline
\end{tabular}

Table 3. Plant species in Sundarban forest.

\begin{tabular}{ll}
\hline Plant species & $\begin{array}{l}\text { Species observed in Sundarban } \\
\text { forest }\end{array}$ \\
\hline Legumes & 35 \\
Grasses & 29 \\
Sedges & 19 \\
Euphorbias & 18 \\
50 true mangrove plant & \\
$\begin{array}{l}\text { species recorded } \\
\text { throughout the globe }\end{array}$ & Sundarban alone contain 35 species \\
\hline
\end{tabular}

Table 4. Within the forest habitats there are numerous types of species present in Sundarbans.

\begin{tabular}{ll}
\hline Faunal species & Diversity \\
\hline Mammals & 50 species \\
Inland and migratory birds & 320 species \\
Reptiles & 53 species \\
Amphibians & 8 species \\
Fish & 400 species \\
Protozoans & 106 species \\
Birds & 315 species \\
Snake & 18 species \\
\hline
\end{tabular}

(Source: Rahmanand and Asaduzzaman 2010).
Table 5. Fish diversity of Sundarban ecosystem.

\begin{tabular}{lll}
\hline Fish diversity & Family & Species \\
\hline Pelagic fish & 27 & 53 \\
Demersal fish & 49 & 124 \\
Shrimps & 5 & 24 \\
Crabs & 3 & 7 \\
Lobster & & 8 \\
\hline
\end{tabular}

(Source: Pasha and Siddiqui 2003)

illicit removal of timber, firewood from the forests and the absence of sustainable management practices are the major forest conservation problems in the area. The rapidly expanding shrimp farming industry possesses the crucial cause for deteriorating the mangrove forests in Bangladesh. Moreover, recently, mangroves have been used for fish, shrimp and especially giant tiger prawn Penaeus monodon (Fabricius, 1798) farming (Chowdhury and Ahmed, 1994). The Chokoria Sundarban has been completely destroyed in recent years because of shrimp farming (Iftekhar and Islam, 2004). The Sundarbans mangrove forest ecosystem 
also has become vulnerable to pollution such as oil spillage, heavy metals, agrochemicals-especially pesticides and nutrient enrichment-which may have changed the mangrove ecosystem's biogeochemistry (Rahman et al., 2009). The dyamics of Sundarbans is mainly maintained by sedimentations from the three major rivers Ganga, Bramhaputra and Meghna. Both the spatial and temporal influences have been demonstrated on the salinity in this region. While describing mangrove forest of Sundarbans, general tendency is to describe this forest as 'Pristine' and totally devoid of any human intervention (Ray, 2008). The estuary remained eutrophic for most time of the year and mesotrophic - eutrophic during the summer months. Overload of nutrients flowing into the estuary resulted in high levels of dissolved Nitrogen, Phosphorus, Silicate and supporting high algal growth. The Correlation coefficient $(\mathrm{p} \ll 0.2)$ of all the parameters signifies that these components play crucial role to drive the trophic level of the estuary. The coefficients of the regression equation indicate that phosphate, DO, turbidity, nitrogen and silicate control the production of algal biomass (and hence eutrophic state) in decreasing order of influence (Manna et al., 2010). Mangroves are the only woody halophytes dominated ecosystem situated at the confluence of land and sea, they occupy a harsh environment, being daily subject to tidal changes in temperature, water and salt-exposure and varying degree of anoxia (Alongi, 2002). Eutrophication as well as presence of toxic Dinoflagellates and Cyanophyceae in the tidal creek of Sundarbans estuary definitely revealed the deteriorated status of the water quality (Manna et al. 2010).

The mangrove forest Sundarbans provides an important defence in limiting climate change impacts, providing protection to coastal areas from tsunamis and cyclones. Each year about eight storms with sustained wind speeds greater than $63 \mathrm{~km} / \mathrm{hr}$ form in the Bay of Bengal, with an average of two becoming tropical cyclones. Tropical cyclones Sidr in 2007 and Aila in 2009 caused extensive damage. Mangroves serve each year as a biological shield protecting coastal communities from the worst effects of storm surge. Loss of mangroves escalates the disaster risk for local populations from storm surge and flooding. The damage to Sundarbans caused by recent cyclone Sidr has been preliminary assessed at $\$ 142.9$ million. It has left $26 \%$ of the forest severely damaged (Saadi, 2010). Climate change is set to damage biodiversity of the Sundarbans increasing the immersed areas and salinity of water in coastal areas. A report by UNESCO, entitled "Case Studies on Climate Change and World Heritage", has stated that an anthropogenic $45 \mathrm{~cm}$ rise in global sea level (likely to happen by the end of the twenty-first century, according to the Intergovernmental Panel on Climate Change), combined with other forms of anthropogenic stress on the Sundarbans, could lead to the destruction of $75 \%$ of the Sundarbans mangroves (UNESCO, 2007).

\section{Economical importance of Sundarbans}

Provisioning services: Timber and fish are major valuable provisioning services of Sundarbans. Total volumes of extracted timber and fish as well as annual revenue from these services were not consistent in every year during the period of 2001-02 to 2009-10. This may be due to variation of timber and fish species as well as their quality. Overall trend of timber extraction was decreasing over the years. This could be due to moratorium on commercial harvesting of timber from Sundarbans (moratorium imposed in 1989; Islam, 2010). Only the revenue from timber collected after natural calamities as well as timber seized from illegal encroachers were recorded by Forest Department, which were accounted in the present study. On the other hand, fish harvesting was increasing over the same period. Similar results were found in the study of livelihood dependency on Sundarbans. The average annual extraction of timber from Sundarbans was about $3567 \mathrm{~m}^{3}$ during 2001-02 to 2009-10, which is comparatively lower than previous study (nearly 9800 $\mathrm{m}^{3}$ in 1997, IRMP, 1998). It indicates that the timber extraction was decreasing over the past years. The average economic value of extracted services from Sundarbans was US\$ 74 per hectare per year for the period of 2001-02 to 2009-10, whereas economic value of timbers in mangrove of Indonesia was US\$ 67 per hectare per year (Ruitenbeek, 1992). The extractions of services from Sundarbans not only depend on the price of the services but also other factors in the market mechanisms. The average annual extraction of fish from Sundarbans was about 6180 tonnes for the period of 2001-02 to 2009-10, which is comparatively higher than previous records (5699 tonnes per year) of 198687 to 1993-94 (DFO, 1995). This may be due to increase in number of fish collectors and fish extraction (Uddin et al., 2013).

Cultural services (tourism): Economic value of cultural services of Sundarbans, as measured by tourism, shows that the number of tourist and annual revenue were increasing for the last 9 years. This result indicates that Sundarbans is being attracted by growing number of tourists for recreation in recent years. However, economic value of tourism in Sundarbans (nearly US\$ 40 thousands per year from whole Sundarbans) is still less compared to other mangrove ecosystem like Sri Lanka (US\$ 933 for domestic and US\$ 1196 for international tourists per hectare per year) (Batagoda, 2003). Promotion of ecotourism, special events and festivals in Sundarbans can increase revenue from tourism (IRMP 1998). Tourism friendly infrastructures are also necessary to promote tourism in Sundarbans (Uddin et al., 2013).

Regulatory services (coastal protection): The coastal protection value of Sundarbans was estimated almost US\$ 42 million/year, which is the highest value among all ecosystem services of Sundarbans. The estimated value provides an indication that Sundarbans has great importance for coastal protection benefits to the 
coastal communities in Bangladesh. Sundarbans mangrove saves lives and properties of coastal communities acting as barriers against winds and storm surges (Hirway and Goswami 2007; Rahman 2009). Mangroves also serve as coastal defence and reduce coastal flooding and coastal erosion (SCBD, 2009). If we could estimate the value for reduction of coastal flood and erosion by Sundarbans together with value for coastal protection from cyclone and storm surge, the total value of regulatory services would be much higher (Uddin et al., 2013).

\section{Conclusion}

Sundarbans, the world's greatest continuous mangrove expanse, has substantial ecological and economical importance at local, national and global level. The total number of people directly employed in the Sundarbans is estimated about 500,000 to 600,000 numbers for a period of 6 months per year. Besides these 120,000 tourists visit Sundarbans heritage site per year and about 50,000 fishermen and other stakeholders work daily in the Sundarbans. The annual value of the wood products removed from the Sundarbans reserve forest is 100 million USD and the value of standing timber has been calculated at 2.09 billion USD. The annual value of fish caught from Sundarbans is 304 million USD, which is three times larger than the annual value of forest products, i.e. 102.09 USD from wood products and value of standing timber. Shrimp culture and tourism will be the main economic activities in the near future in Sundarbans. The annual income of livelihoods from fish was higher than other provisioning services of Sundarbans, which is similar to the Media creek mangrove of Kenya. The study showed that average annual income from fish was almost US\$ 390 per household per year in Sundarbans, whereas it is lower in Bhitarkanika mangrove in India (US\$ 68 per household per year) and US\$ 90 per households per year in Mida Creek mangrove forest, Kenya. Furthermore, since future climate change will have impact on the ecosystem services of Sundarbans, the dependent livelihoods will also be affected by changes of production and value of services. Employment and income generation of livelihoods from Sundarbans will be changed

\section{ACKNOWLEDGEMENTS}

The authors are thankful to many researchers whose published studies have been used freely in preparing this overview. We acknowledge the support from the Director, Central Inland Fisheries Research Institute, Barrackpore and Dr. Sumit Homechoudhury, Professor, Department of Zoology, Calcutta University.

\section{REFERENCES}

Anouti, F.A. (2014). Bioaccumulation of Heavy Metals within Mangrove Ecosystems. J Biodivers Endanger Species, 2 (2): 1000e113.

Ali, M., Kabir, M.A. and Hoque, A.T.M.R. (2006). People, policy, and perpetuity: Sustainability indicators of
Bangladesh forestry. Electronic Green Journal. URL: http://escholarship.org/uc/item/2c34v67q.

Alongi, D.M. (2002). Present state and future of the world's mangrove forests. Environ. Cons.,29: 331-349.

Alongi, D. M. (2009). 'Paradigm Shifts in Mangrove Biology', In: Perillo, G., Wolanski, E., Cahoon, D. and Brinson, M. (eds) Coastal Wetlands: An Integrated Ecosystem Approach; London, Elsevier.

Amin, M.N. (2002). Biodiversity and Floristic Composition of Sundarbans in Bangladesh, archives of EnviroNews Newsletter of ISEB India. 8: 4.

Annandale, N. (1922). The marine elements in the fauna of Ganges. Bijdr Dierk. 22: 143-154.

Banerjee, A. (1998). Environment, population and human settlements of Sunderban Delta. $1^{\text {st }}$.

Banglapedia, (2010). National Encyclopedia of Bangladesh. URL: http://banglapedia.net.english/index.htm.

Batagoda, B.M.S. (2003). The economic valuation of alternative uses of mangrove forests in Sri Lanka. UNEP/ Global Programme of Action for the Protection of the Marine Environment from Land-based Activities, The Hague.

Bose, T., Baguli, T.K., Ghosh, A.K. and Naskar, K.R. (1999). A review of shell fish and fin fish species from the brackish water fisheries of the Sundarbans and their impact on the mangrove.

Bose, S. (2002). The Sundarbans Biosphere: A Study On Uncertainties And Impacts In Active Delta Region. Centre for Built Environment, Kolkata.

Champion, H.G. (1936). A preliminary survey of the forest types of India and Burma. Indian Forest Reocrd (New Series) 1: 1-286.

Chaudhuri, A.B. and Choudhury, A. (1994). Mangroves of the Sundarbans, India. IUCN, Bangkok.

Mangroves of the Sun- derbans: Volume 1 India, IUCN, Bangkok.

Choudhury, M.A. (1984). Integrated Development of the Sundarbans, Bangladesh: Silvicultural Aspects of the Sundarbans, FAO Report No/TCP/BGD/ 23 09Wf, W/ R003.

Choudhuri, A.B. and Choudhury, A. (1994). In Chowdhury, R.A. and Ahmed, I. (1994). History of forest management Bangladesh. In: Mangroves of the Sundarbans. Hussain Z, Acharya G. (eds.), pp.155-180. IUCN Wetlands Program, Gland, Switzerland.

Das, S. K., Sarkar, P. K., Saha, R., Vyas, P., Danda, A. A. and Vattakavan, J. (2012). Status of Tigers in 24-Parganas (South) Forest Division, West Bengal, India. World Wide Fund for Nature-India, New Delhi.

Debnath, H,S, (2001), Sundarbans biosphere reserve (data collection and identification of gaps). State of art report, Biosphere Reserve Information Service (BRIS), MOEF project ecology. In: Guha Bakshi D N, Sanyal P, Naskar K R (eds) Sundarbans Mangal. Naya Prakash, Calcutta, pp 539-547 edition, Concept Publishing Company, New Delhi.

D.F.O. (1995). Annual report, Bangladesh Forest Department, Khulna, Bangladesh.

Environmental Sciences, University of Chittagong. Nibedon Press Limited, Chittagong.

Food and Agriculture Organization (2000). State of World's Forests 2003. FAO, Rome. Italy.

Gopal, B. and Chauhan, M. (2006). Biodiversity and its conservation in the Sundarbans Mangrove Ecosystem, Aquat. Sci. 68: 338-354. 
Gopalkrishnan, V. (1971). The biology of the HooghlyMatlah estuarine system (West Bengal-India) with special reference to its fisheries. J Mar Boil Asso India ,13 (2): 182-194.

Junk, W. J., Brown, M. T., Campbell, I-C., Finlayson, M., Gopal, B., Ramberg, L. and Warner, B. G., (2006). The comparative biodiversity of seven globally important wetlands: a synthesis. Aquatic Science, 68: 400-414.

Khan, M. (2011). Tigers In The Mangroves: Research and Conservation of the Tiger in The Sundarbans of Bangladesh. Aranyak Foundation. 189 p.

Hirway, I.and Goswami, S. (2007). Valuation of coastal resources: The case study of mangroves in Gijrat. Academic foundation, New Delhi: 170.

Hora, S.L. (1934). Brackish water animals of the Gangetic delta. Curr Sci 2:426-427.http://www.wetlands.org/ reports/ris/2BD001en.pdf.

Iftekhar, M.S. and Islam, M.R. (2004). Degeneration of Bangladesh's Sundarbans mangroves: a management issue. The Int. For Rev., 2: 123-135.

India and their environmental implications. Environment International, 30:1089-1098

Information Sheet on Ramsar Wetlands, RIS, 2001 (visited on $15 / 05 / 2015$ ).

Islam, A.K.M.N. (1976). Contribution to the study of the marine algae of Bangladesh- Bibliotheca Phycologia. 19:15.

Islam, M.S.N. and Gnauck, A. (2009). Threats to the Sundarbans Mangrove Wetland Ecosystems from Transboundary Water Allocation in the Ganges Basin: A Preliminary Problem Analysis. Int. J. Ecol. Econ. Stat., 13: 6478.

Islam, K.M.N. (2010). A study of the principal marketed value chains derived from the Sundarbans reserved forest. USAID, Bangladesh.

I.R.M.P. (1998). Integrated Resource Development of the Sundarbans Reserve Forest, Bangladesh. FAO/UNDP Project BGD/84/0561.

Jain, S.K.and Sastry, A.R.K. (1983). Botany of some tiger habitats in India. Botanical Survey of India, Howrah. Pp. 40-44.

Kemp, S.W. (1917). Notes on the fauna of the Matlah River in the Gangetic delta. Rec Indian Mus., 13 (4): 233-241.

Khan, R.A. (2003). Fish faunal resources of Sundarbans estuarine system with special reference to the biology of some commercially important species. Records of the Zoological Survey of India. Occasional paper 209:150 $\mathrm{pp}$

Khatun, B.M.R. and Syed hafiz, (1987). Taxonomic studies in the genus Avicennia L. from Bangladesh. Bangladesh J. Bot., 16 (1): 39-44.

Macintosh, D.J. (1982). Fisheries and aquaculture significance of mangrove swamps, with special reference to the Indo-West Pacific region. In: Muir, J.F. and Roberts, R.J. (eds.), Recent Advances in Aquaculture. Croom Helm, England, pp. 4-85.

Macintosh, D.J. and Ashton, E.C. (2002). A Review of MangroveBiodiversity Conservation and Management. Report to WorldBank. Centre for Tropical Ecosystem Research, University of Aarhus, Denmark. 8:71 pp.

Macnae, W. (1974). Mangrove Forest and Fisheries. FAO, Rome IOFC:DEV, 74:34-35

Management, Centre for Tropical Ecosystems Research, University of Aarhus, Denmark.
Mandal, A.K. (2003). The Sundarbans of India: a development analysis. Indus Publishing Company (Retrieved 2009) $10-27$.

Mandal, A.K. and Ghosh, R.K. (1989). Sundarbans - A Socio Bio-ecological study, Bookland Pvt. Ltd., Calcutta pp 89.

Mandal, A.K. and Nandi, N.C. (1989). Fauna of Sundarbans mangrove ecosystem, West Bengal, India. Fauna of Conservation Areas, Zoological Survey of India, 3:116pp.

Mandal, B., Mukherjee, A., Sarkar, S. and Banerjee, S. (2012). Study on the Ornamental Fin Fish of Indian Sundarbans with Special Reference to Few Floral Sources for Carotenoid Pigmentation, World Journal of Fish and Marine Sciences., 4 (6): 566-576.

Manna, S., Chaudhuri, K., Bhattacharyya, S.and Bhattacharyya, M. (2010). Dynamics of Sundarbans estuarine ecosystem: eutrophication induced threat to mangroves Saline Systems 6:8 http:// www.salinesystems.org/content/6/1/8.

Matthes, H. and Kapetsky, J.M. (1988). Worldwide compendium of Mangrove associated Aquatic species of Economic Importance FAO, Rome FAO Fishery Circular No. $814: 238$

Mitra, A., Banerjee, K. and Bhattacharyya, D.P. (2004). The other face of Mangroves (p. 185). Published by Department of Environment, Government of West Bengal (India) Press, Kolkata.

Mitra, A., Gangopadhyay, V., Dube, A., Schmidt, A.C.K. and Banerjee, K. (2009). Observed changes in water mass properties in the Indian Sundarbans (northwestern Bay of Bengal) during 1980-2007. Current Science, 97 (10): 1445-1452.

MoEF. (2004). Joint Tiger census - 2004, Bangladesh Forest Department under the Ministry of Environment and Forests (MoEF). URL: http://www.bforest.gov.bd/.

Moorthy, P. (1995). Effects of UV-B radiation on mangrove environment: Physiological responses of Rhizophora apiculata Blume (p. 130). Ph.D thesis, Annamalai University, India.

Mukherjee, A.K. (1975). The Sundarbans of India and its biota. Journal of the Bombay Natural History Society, 72: 1-20.

Naskar, K. (2009). Plant wealth of the lower Ganga Delta: an eco-taxonomical approach. 1:10-27.

Naskar, K.R. (2000). Ecology and environment of Indian Sundarbans in West Bengal, (in Bengal). in Paschimbanga published by the Department of Information and culture, Government of West Bengal.

Naskar, K.R. (2004). Manual of Indian Sundarbans. Daya Publishing House, New Delhi

Naskar, K.R. and Guha Bakshi, D.N. (1987). Mangrove swamps of the Sundarbans. Naya Prokash, Calcutta.

Naskar, K.R. and Mandal, R.N. (1999). Ecology and Biodiversity of Indian Mangroves. Daya Publishing House, New Delhi, India.

Ong, J.E. (1995). The ecology of mangrove conservation and management. Hydrobiologia, 295: 343-351.

ODA (1985). Project report 140: A forest inventory of the Sunderbans, Bangladesh. Survey, U.K.: Land resources development centre, Overseas Development Administration., Overseas Development Administration(ODA)

Pantulu, V.R. (1966). Contribution to the study of the biology and fishery of some estuarine fishes. $\mathrm{PhD}$ thesis, University of Calcutta.

Pasha, M. and Siddiqui, N. (2003). Sunderbans. Banglapedia: National Encyclopedia of Bangladesh. 
Islam S. (ed.) Asiatic Society of Bangladesh, Dhaka, Bangladesh. pp. 133-138.

Prain, D. (1903). The flora of Sundarbans. Records of the Botanical Survey of India, 114: 231-272.

Rabbani, A.G. and Sarker, M.S. (1997). Study on the current status of the fish extraction and revenue collection from the Sundarbans Reserve Forest. A Project Thesis-Fisheries and Marine Resource Technology Discipline, Khulna University, Khulna, Bangladesh: $57 \mathrm{pp}$.

Rahman, M.M., Chongling, Y., Islam, K.S.and Haoliang, L. (2009). A Brief review on pollution and ecotoxicologic effect on Sundarbans mangrove ecosystem in Bangladesh. IJEE. 1:369-382.

Rahman, M.R. and Asaduzzaman, M.R. (2013) Ecology of Sundarban, Bangladesh. J. Sci. Foundation, 8 (1\&2): 35-47.

Rahman, M., Khatun, S., Hossain, M. B., Hassan, M. N. and Nowsad, A. A. K. M. (2013). Present Scenario of Landing and Distribution of Fish in Bangladesh. Pakistan Journal of Biological Sciences, 16 (22): 1488.

Rahman, A.A. (2009). Seal the Deal in Copenhagen: The Most Vulnerable Communities Demand Tearfund.

Rahman, M.S. (2009). Ecology and management of Sundarban: A Rich Biodiversity of the World's Largest Mangrove Ecosystem. URL: http:// docs.google.com/viewer.

Ray, S. (2008). Comparative study of virgin and reclaimed islands of Sundarban mangrove ecosystem through network analysis. Ecol. Model. 215:207-216.

Ruitenbeek, J. (1992). The rainforest supply price: A tool for evaluating rainforest conservation expenditure. Ecological economics, 6 (1): 57-78.

Aadi, M.L.K. (2010). Hurricane Sidr claims beautiful mangroves. URL: http://www.islamonline.net.

Saenger P (2002) Mangrove ecology, silviculture and conservation, Dordrecht, Kluwer Academic Publishers, The Netherlands.

Saenger, P., and McConchie, D. (2004). Heavy metals in mangroves: methodology, monitoring and management. Envis Forest Bulletin, 4, 52.

Sanyal, P. (1983). Mangrove tiger land, the Sundarbans of India. Tigerpaper, 10 (3): 1-4

Sanyal, P. (1999). Sundarbans-the largest mangrove diversity on globe. In: Guha Bakshi DN, Sanyal P, Naskar KR (eds) Sundarbans Mangal. Naya Prakash, Calcutta, pp. 428-448.

S.C.B.D. (2009). Connecting Biodiversity and Climate Change Mitigation and Adaptation. Report of the Second Ad Hoc Technical Expert Group on Biodiversity and Climate
Change Montreal : Secretariat of the Convention on Biological Diversity Technical Series No 41: 126.

Seidensticker, J. and Hai, M. (1983). The Sundarbans Wildlife Management Plan: Conservation in the Bangladesh Coastal Zone. IUCN, Gland, Switzerland.

Sen, N.and Naskar, K.R. (2003). Algal Flora of Sundarbans Mangals. Daya Publishing House, Delhi 110035.

Sen, T.K. (1975). Fish and fisheries aspects of the Sundarbans, West Bengal. Sci Cult., 41 (10): 500-502.

Shetty, H.P.C., Saha, S.B. and Ghosh, B.B. (1961). Observations on the distribution and fluctuations of plankton in the Hooghly-Matlah estuarine system with notes on their relation to commercial fish landings. Indian $J$ Fish., 8 (8):326-363.

Siddiqi NA. 2001. Mangrove forest in Bangladesh (Institute of Forestry and Environmental Science, University of Chittagong), pp201.

Singh, H.R., Chong, V.C., Sasekumar, A. and Lim, K.H. (1994). Value of mangroves as nursery and feeding grounds. In: Wilkinson CR, Suraphol S and Chou LM (eds.), Status Reviews. Proceedings of the Third ASEAN-Australia Symposium on Living Coastal Resources, Chulalongkorn university, Bangkok 1:105-122.

Talwar, P.K.and Joglekar, A. (1970). On a new species of 'Wak' Lin 1938 (Pisces: Sciaenidae) from Hooghly estuary. J Int Fish Soc. India, 1:32-36.

Twilley, R.R., C hen, R. and Hargis, T. (1992). Carbon sinks in mangroves and their implica tion to carbon budget of tropical ecosystems. Water, Air and Soil Pollution, 64: 265-288.

Uddin, H. M. B. (2011). Exotic species invasion and biodiversity in Bangladesh forest ecosystems (Doctoral dissertation, Universität Bayreuth).

Uddin, M.S., van Steveninck, E.D.R., Stuip, M. and Shah, M.A.R., 2013. Economic valuation of provisioning and cultural services of a protected mangrove ecosystem: a case study on Sundarbans Reserve Forest, Bangladesh. Ecosystem Services, 5, pp.88-93.

UNESCO (2007). Climate change threatens UNESCO World Heritage sites, UN. URL: http://whc.unesco.org/en/news/319.

Zaman, S., Bhattacharyya, S.B., Pramanick, P., Raha, A.K., Chakraborty, S.and Mitra, A. (2013). Rising water salinity: A threat to mangroves of Indian Sundarbans Water Insecurity: A Social Dilemma Community, Environment and Disaster Risk Management 13:167-183.

Zöckler, C., Balachandran, S., Bunting, G.C., Fanck, M., Kashiwagi, M., Lappo, E.G., Maheswaran, G., Sharma, A., Syroechkovski, E.E. and Webb, K. (2005). The Indian Sunderbans: an important wintering site for Siberian waders. Wader Study Group Bull., 108: 42-46. 